\title{
An Udmurt Flute
}

\section{Irina Pchelovodova}

e-mail: orimush@mail.ru

\begin{abstract}
The article gives a complete description of the $u z^{\prime} y g u m y$, the Udmurt traditional flute. Published articles by Russian researchers and new field material recorded during expeditions between 2004 and 2009 are used as the main sources. For the first time the process of manufacture of the instrument is observed, the territory of its existence is outlined, preferable sizes of the instrument are given, the way of playing and repertoire of executed folk tunes are described.
\end{abstract}

Keywords: end-blown flute, manufacture, methods of playing the instrument, repertoire, Udmurt, traditional musical instruments

Today, there are separate articles devoted to this or that musical instrument, although the culture of Udmurt traditional instruments is still generally poorly investigated in Russian ethno-organology.

The investigation of Udmurt musical instruments began in the middle of the $20^{\text {th }}$ century with the greatest attention paid to chordophones. The oldest Udmurt musical instrument the krez' (zyther) is especially distinguished among them (Buch 1882; Belyaev 1989; Gippius, Eval'd 1989; Golubkova 1978, 1989, 1992; Karpov 1989; Kungurov 1992). The sound is produced by strings stretched between two fixed holders. A musical collection of folk 
tunes performed on the kubyz (violin) was published in 2004 (Nurieva 2004, 2005; Pchelovodova, Demeter 2011; Pchelovodova 2012). There is much less information about Udmurt aerophones. Significant information about them appeared after field expeditions between 2004 and 2009 (Pchelovodova 2010). This article is devoted to a complete description of the Udmurt traditional flute, the $u z^{\prime}$ 'yumy, based on materials from published and field sources.

The instrument was named after the umbellate uz'ygumy/gumy plant (Angelica) from which it is made and it is an archaic musical instrument of the Udmurt (photo 1). This is an end-blown labial fricative flute $50-80 \mathrm{~cm}$ in length with a whistle hole but no finger holes. The uz'ygymy produces only natural sounds that depend on the material and the size of the instrument. A musician can modify the sound pitch of the instrument by closing the lower hole with a forefinger, tightening the lips and changing the blowing force. There are some similar musical instruments in the traditional cultures of the Finno-Ugric people (the Komi have the otika pöl'an, the Mari the shiyaltysh, the Karelians and Finns the siirtotulppaiset huilut, and the Hungarians the tilinkó) (Chistalev 1984; Gerasimov 1996; Leisiö 1983; Vargyas 2005), the Turkic people (the Tatars and the Bashkirs have the kuray, the Chuvash the shahlich) (Makarov 2006; Chuvashi 1970), the Slavonic people (the Russians have the travyanaya dudka / kalyuka) (Kiryushina 1989), the peoples of Siberia (the Tuvinians have the murgu, the Altais the shoor) (Suzukey 2007), the Scandinavian people (the Norwegians have the spaltefløyta) (Sevåg 1973), the South American Indians (Izikowitz 1935) and many others. Probably one of the reasons for the popularity of the instrument is the simplicity of its manufacture. All these instruments are made from the stalk of umbellate plants such as Angelica, Reed, Rhubarb, etc. 


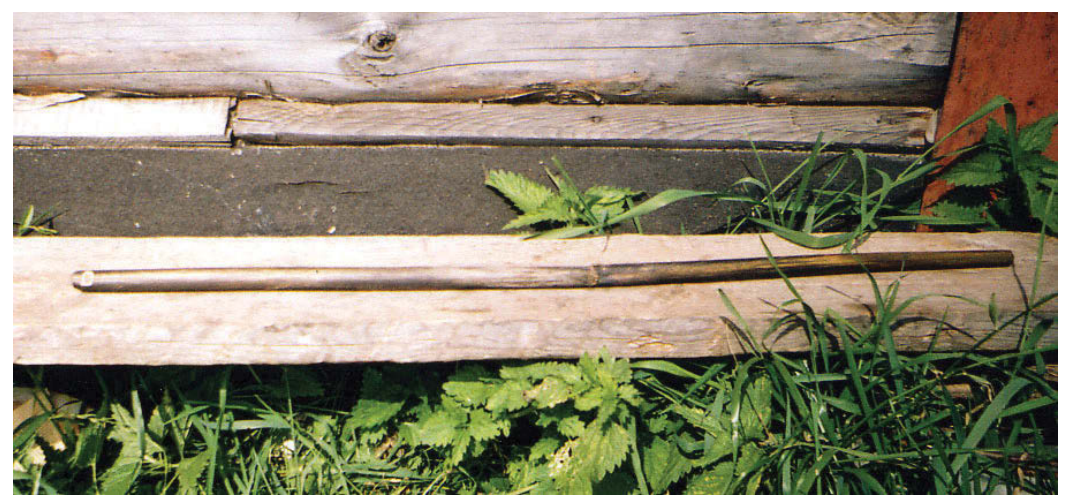

Photo 1. Uz'ygumy. Novyy Untem, Kez district, Udmurt Republic. Photo by Irina Pchelovodova, 2004.

\section{The data from written sources}

The first data on the uz'ygumy appeared in an article by Soviet researchers Evgeniy Gippius and Zinaida Eval'd titled "On the Study of the Poetic and Musical Style of Udmurt Folk Songs" (Gippius, Eval'd 1989). In the article authors describe the uz'ygumy and the chipchirgan (a natural trumpet), which hadn't been mentioned previously. Music samples of traditional folk tunes written at Evgeniy Gippius's request in 1936 were published only in 1989. Two folk tunes (wedding and recruiting) were presented there.

In 1989 the editors added the article "Information about Udmurt Folk Musical Instruments" by musicologist Viktor Belyaev (Belyaev 1989), which the editors thought had been written at Evgeniy Gippius's request. The value of the work consists in the attempt to classify Udmurt musical instruments. Viktor Belyaev divides them into percussion instruments, stringed instruments and wind instruments, which are sub-divided into families of trumpets (chipchirgan), flutes (uz'ygumy) and clarinets (byz (bagpipes)). Some 
more music samples were published in the Udmurt Folk Songs collection by Irina Travina (Travina 1964). However, the author does not give the characteristics of instruments.

Between the 1970s and 1990s new works were published containing descriptions of construction, methods of playing and the technical possibilities of the Udmurt flute (Vertkov, Blagodatov, Yazovitskaya 1975; Golubkova 1978, 1989, 1992; Karpov 1989; Kungurov 1992). All publications reported that the uz'ygumy had disappeared from tradition. Only the works of modern ethnologist Elena Popova, devoted to Udmurt and Besserman ${ }^{1}$ children's game culture, contain information on the $u z^{\prime} y$ gumy shulan, a whistle made from angelica $15-50 \mathrm{~cm}$ in length (Popova 2005).

\section{The field ethnographical materials}

The expedition materials of the Udmurt Institute of History, Language and Literature at the Udmurt Federal Research Centre of the Ural Branch of the Russian Academy of Science (below UIIYaL FITs UrO RAN) from 2004-2009 have shown that the tradition of playing the $u z^{\prime}$ 'yymy isn't lost but survives in practice. Modern field ethnographic materials have expanded knowledge about the Udmurts end-blown flute. These data have allowed us to specify an area where the instrument is spreading and to reveal some varieties of Udmurt flute.

We recorded the playing of an $u z^{\prime} y g u m y$ for the first time in the north of the Udmurt Republic in 2004-2005 and then again in $2007^{3}$. The instrument was $49 \mathrm{~cm}$ in length with a whistle hole and no finger holes. As material for the instrument the player Evgeniy Khudyakov (1939-2009) used a rubber hose (photo 2). He considered that the traditional material (umbellate plant stalk) was too short-lived and impractical. Therefore he used modern materials such as a rubber hose, plastic and aluminium tubes. 
But Khudyakov had tried to keep the traditional form of the instrument. Thus he made the top part of the instrument from a wide tube and for the bottom part used a narrower tube. When making the uz'ygumy from a plant stalk Khudyakov used human measurements to find the length of the instrument, depending on length of the arm 78-82 cm, with the width of the instrument corresponding to the width of the thumb.

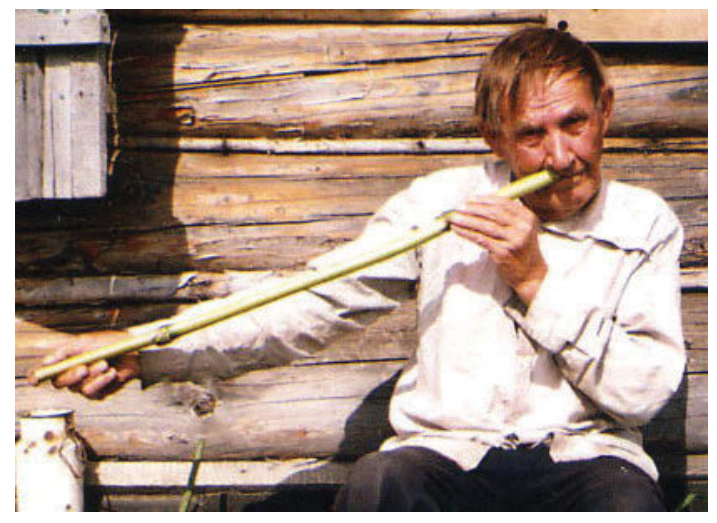

Photo 2. Uz'ygumy player Evgeniy Andreevich Khudyakov. Novyy Untem, Kez district, Udmurt Republic. Photo by Irina Pchelovodova, 2004.

The other players (Aleksey Semyonov, 1938 and Nikolay Chupin, 1925) had shorter instruments, $40-60 \mathrm{~cm}$ in length. In rare cases the $u z^{\prime}$ ygumy had finger holes, but no more than two and cut roughly.

In 2008 data, the uz'ygumy was fixed in the south of Udmurt Republic for the first time ${ }^{4}$. The construction of the instrument was similar to the previous examples mentioned. The flute was cut from 
between crosspieces of a plant and was 40-42 cm in length with no finger holes. The performer, Anatoliy Bykov (b. 1938), preferred instruments made from a fresh, not dried, plant stem because the sound is more sonorous (photo 3 ).

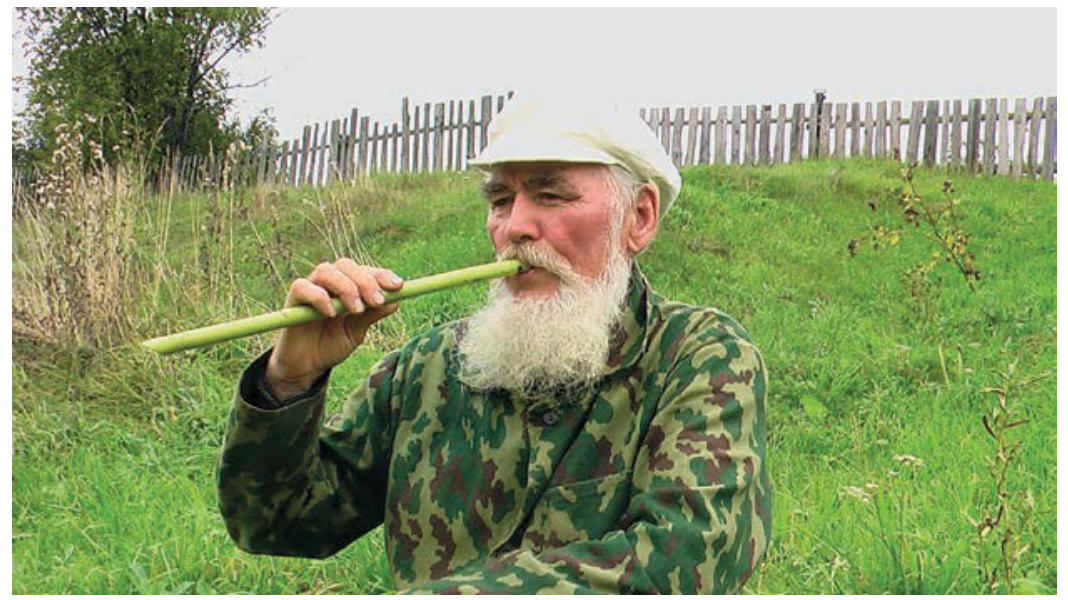

Photo 3. Uz'ygumy player. Anatoliy Dmitrevich Bykov. Chutozhmon, Malaya Purga district, Udmurt Republic. Photo Irina Pchelovodova, 2009.

The Siberian Udmurt living in the Tomsk region of Russia also had similar a instrument, also known as a $u z^{\prime} y g u m y^{5}$. Vasilisa Perevozchikova (b. 1929) said that the instrument had been made from chushni (Anthriscus sylvestrus). At the upper end of the instrument there was a whistle plug while the other end was closed by the plant's natural crosspiece. Probably, there were also finger holes.

All performers have their own methods of playing the instrument. When playing the uz'ygumy musicians put it to their mouths in such manner that the whistle hole is in the bottom part of the tube, or more rarely above. Air is blown into the hollow tube of 
the instrument and the bottom part is closed. In the south of the Udmurt Republic one performer, Anatoliy Bykov, demonstrated different ways of playing the flute. Thus he created melodies through the mobility of his lips and by changing the instrument position.

As has been said before one of the reasons for the popularity of the instrument was the simplicity of its making. As a rule the Udmurt flute was mainly used by shepherds. In addition, playing the uz'ygumy accompanies young people's outdoor festivals, returning to village after haymaking, and when searching for honey. During the Great Patriotic War the uz'ygumy was the only musical instrument in villages.

It was possible to play uz'ygumy solo or in an ensemble. Performers held competitions with the best performers estimated on skill of playing. Only male shepherds and young guys could play the instrument. In traditional culture grazing was men's work and so women didn't play the uz'ygumy.

Each musician has his own repertoire, for example Evgeniy Khudyakov performed only dance (ekton gur) and chastushka tunes. Sometimes he played in ensembles with an harmonica if the key of the instruments concurred. Masterly uz'ygumychi (player) Ivan Shabalin (1902-19??) from Selty district in the Central part of Udmurt Republic played different melodies such as dance tunes (ekton gur), work tunes (pur kel'an gur, tunes performed during timber rafting), ceremonial tunes (kuno gur, 'guest tune'), borrowed melodies (dzh'uch gur, 'Russian tune') and also his own melodies. It is possible to play song melodies on the instrument as well as improvisations.

At a preliminary stage of our research we can say that Udmurt end-blown flute is a culture phenomenon that occurs in all Udmurt groups. We can distinguish two types of uz'ygumy according to construction (design). The first type is the open end-blown flute with a whistle hole and without finger holes (or with no more than two). The length of the instrument depends on the length of the 
musician's arm. However the length of the instrument could be shorter depending on the desire of the performer to tune to a specific range. The second type is the closed end-blown flute with a whistle plug and probably with finger holes too.

In conclusion, let us observe that today the uz'ygumy is not present in living tradition. We must acknowledge the fact that transmission of playing has been interrupted. Nevertheless, the uz'ygumy, its making and playing, have continued in the repertoires of some folklore ensembles in Udmurtia, such as Aykay, the Udmurt state theatre of folk songs and dances; the folklore and ethnographic ensemble Chipchirgan; and the folklore ensemble Soroka ('magpie') from the Republic's musical college. One of the present masters and makers is Evgeniy Bikuzin.

\section{Notes}

1 The Besserman people are ethnically a group of Udmurt with a strong Turkic influence.

${ }^{2}$ Folklore and ethnographic expedition of the Udmurt Institute of History, Language and Literature in 2004: Kez district of Udmurt Republic. Participants: T. Vladykina, A. Mutina, I. Pchelovodova, A. Nikulin, E. Lozhkina, T. Vladykina. In $2005 \mathrm{Kez}$ district of Udmurt Republic. Participants: I. Pchelovodova, A. Nikulin.

${ }^{3}$ Folklore and ethnographic expedition of the Udmurt Institute of History, Language and Literature in 2007: Glazov district of the Udmurt Republic. Participants: I. Pchelovodova.

${ }^{4}$ Folklore and ethnographical expedition of the Udmurt Institute of History, Language and Literature in 2008: Malaya Purga district of Udmurt Republic. Participants: I. Pchelovodova.

5 Folklore and ethnographical expedition of the Udmurt Institute of History, Language and Literature in 2006: Chainsk district of Tomsk region. Participants: I. Pchelovodova in the delegation from Udmurt Republic. 


\section{References}

Belyaev, V. 1989. Spravka ob udmurtskikh narodnikh muzykal'nykh instrumentakh [Information about the Udmurt National Musical Instruments]. E. Gippius, Z. Eval'd. Udmurtskiye narodnyye pesni: Teksty i issledovaniya. Izhevsk: Udmurtskiy institut istorii, yazyka i literatury Uralskogo otdeleniya Rossiyskoy akademii nauk (Pamyatniki kul'tury. Fol'klornoe nasledie), pp. 34-38.

Buch, M. 1882. Die Wotjäken, eine ethnologische Studie [The Votyak. An Ethnologic Study]. Helsingfors: Finnische Litteratur Gesellschaft.

Chistalev, P. 1984. Komi narodnyye muzykal'nyye instrumenty [The National Musical Instruments of the Komi]. Syktyvkar: Komi knizhnoye izdatel'stvo.

Chuvashi. Etnograficheskoye issledovaniye [Chuvash. Ethnographic Research] 1970. Vol. 2. Cheboksary: Chuvashskoye kn. izd-vo.

Gerasimov, O. 1996. Traditsionnyye muzykal'nyye instrumenty mari [The Traditional Musical Instruments of the Mari]. Yoshkar-Ola: Mariyskiy izd.-poligr. kombinat.

Gippius, E., Eval'd, Z. 1989. Udmurtskie narodnye pesni: Teksty $i$ issledovaniya [The Udmurts National Songs: Texts and Researches]. Izhevsk: Udmurtskiy institut istorii, yazyka i literatury Uralskogo otdeleniya Rossiyskoy akademii nauk (Pamyatniki kul'tury. Fol'klornoye naslediye).

Golubkova, A. 1978. Muzykal'naya kul'tura Sovetskoy Udmurtii (1917-1967) [The Musical Culture of the Soviet Udmurtia]. Izhevsk: Udmurtia.

Golubkova, A. 1989. K voprosu o rannikh etapakh formirovaniya muzykal'noy kul'tury udmurtov [About the Early Stages of Formation of Musical Culture of the Udmurt]. Istoki iskusstva Udmurtii. Izhevsk: Udmurtskiy institut istorii, yazyka i literatury Uralskogo otdeleniya Rossiyskoy akademii nauk, pp. 3-11.

Golubkova, A. 1992, Rol' muzykal'nyh instrumentov i instrumental'noy muzyki v dukhovnoy kul'ture udmurtov [The Role of Musical Instruments and Instrumental Music in the Spiritual Culture of the 
Udmurts]. Vestnik UdGU [Bulletin of Udmurt University]. No 6. Izhevsk, pp. 63-69.

Izikowitz, K. 1935. Musical and other sound instruments of the South American Indians: a comparative ethnographical study. Goteborg: Elanders.

Karpov, A. 1989. Drevniye muzykal'nyye instrumenty (Ketnograficheskomu izycheniyu) [The Ancient Musical Instruments (To Ethnographic Studying)]. Istoki iskusstva Udmurtii. Izhevsk: Udmurtskiy institut istorii, yazyka i literatury Uralskogo otdeleniya Rossiyskoy akademii nauk, pp. 12-22.

Kiryushina, T. 1989. Traditsionnaya russkaya instrumental'naya kul'tura [The Traditional Instrumental Culture of the Russian]. Moscow: GMPI im. Gnesinyh.

Kungurov, S. 1992. Udmurtskiye traditsionnyye muzykal'nyye instrumenty [The Udmurt Traditional Musical Instruments]. Izhevsk: RDNT-Dom molodyozhi.

Leisi, T. 1983. Suomen ja Karjalan vanhakantaiset torvi-ja pillisoittimet: nimistö, rakenteet ja historia [The Primitive Trumpet and Pipe Instruments in Finland and Karelia: Organonymes, Constructions and History]. Kaustinen: Kansanmusiikki-instituutti.

Makarov, G. 2006. Traditsionnyye dukhovnyye muzykal'nyye instrumenty tatar Volgo-Kam'ya (Problemy genezisa $i$ istoricheskoy rekonstruktsii) [The Traditional Wind Musical Instruments of the Tatar of the Volga and Kama Region (Problems of Genesis and Historical Reconstruction)]. Kazan: IIALI AN RT.

Nurieva, I. 2004. Pesni zavyatskikh udmurtov [Songs of the Trans-Vyatka Udmurts]. Vol. 2. Izhevsk: Udmurtskiy institut istorii, yazyka i literatury Uralskogo otdeleniya Rossiyskoy akademii nauk (Udmurtskiy fol'klor).

Nurieva, I. 2005. Kubyz/kubyzchi v mezhnatsional'nom kontekste kul'tur [The Kubyz and the Kubyzchi in the International Context of Cultures]. Muzykant v kul'ture: kontseptsii i deyatel'nost'. Sankt-Petersburg: RIII, pp. $46-50$.

Pchelovodova, I., Demeter, M. 2011. Kubyz: sposoby i priyomy igry traditsionnykh ispolniteley [The Kubyz: Ways and Methods of the Play of Traditional Performers]. Otechestvennaya etnomuzykologiya: 
istoriya nauki, metody issledovaniya, perspektivy razvitiya [Russian Ethnomusicology: History of the Discipline, Research Methods, Development Perspectives]. Sankt-Petersburg: Universitetskiy Obrazovatel'nyy okrug Sankt-Peterburga i Leningradskoy oblasti. T. 2, pp. 310-321.

Pchelovodova, I. 2012. Khordofony v traditsionnoy kul'ture udmurtov [The Chordophones in the Traditional Culture of the Udmurt]. Traditsionnaya kul'tura [The Traditional Culture]. No 4, pp. 44-49.

Pchelovodova, I. 2010. Aerofony v sisteme traditsionnoy instrumental'noy kul'tury udmurtov [The Aerophones in the System of Traditional Instrumental Culture of the Udmurt]. Ezhegodnik finno-ugorskikh issledovaniy [Yearbook of Finno-Ugric Studies]. Vol. 1, pp. 95-108.

Popova, E. 2005. Igrushki iz rasteniy v detskoy igrovoy kul'ture udmurtov i besermyan [The Toys from Plants in Children's Game Culture of the Udmurt and Besserman]. Traditsionnaya kul'tura [The Traditional Culture]. No 3, pp. 85-93.

Sevåg, R. 1973. Det Gjallor og det loet. Frå skremmeog lokkereiskapar til folkelege blåseinstrument. Oslo: Norsk Kulturarv.

Suzukey, V. 2007. Muzykal'naya kul'tura Tuvy v XX stoletii [The Musical Culture of the Tuva in the $20^{\text {th }}$ Century]. Moscow: Kompozitor.

Travina, I. 1964. Udmurtskiye narodnyye pesni [The Udmurt Folk Songs]. Izhevsk: Udmurtia.

Vargyas, L. 2005. Folk Music of the Hungarians. Budapest: Akadémiai Kiadó.

Vertkov, K., Blagodatov, G., Yazovitskaya, E. 1975. Atlas muzykal'nykh instrumentov narodov SSSR [Atlas of Musical Instruments of the People of the USSR]. Izd-vo 2-e, dop. i pererab. Moscow: Muzyka, pp. 73-75. 


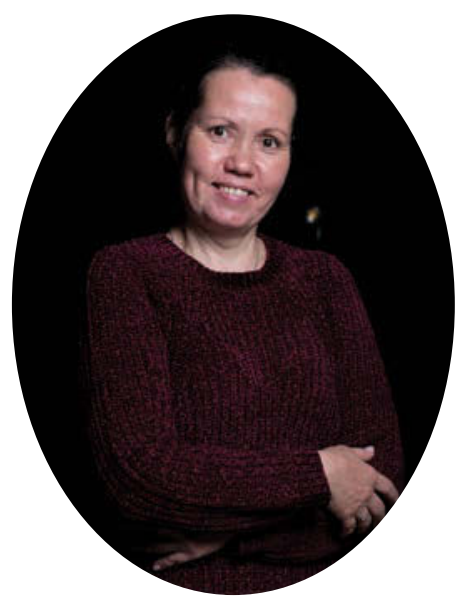

Irina Pchelovodova $(\mathrm{PhD})$ is an ethnomusicologist and a research associate at the Udmurt Institute for Research in History, Language and Literature (Udmurt Federal Research Centre of the Ural Branch of the Russian Academy of Sciences). She is interested in Udmurt folk music, folk song and folk instruments. She teaches at the University and at the Music college; she is the leader of the folklore and ethnographic musical group Chipchirgan.

e-mail: orimush@mail.ru 